\title{
Perbandingan Kadar Kalium Packed Red Cell Berdasarkan Lama Penyimpanan Di Bank Darah RSUP Dr. M. Djamil Padang
}

\author{
Tuti Asryani ${ }^{1}$, Rismawati Yaswir², Zelly Dia Rofinda²
}

\begin{abstract}
Abstrak
Packed Red Cell (PRC) adalah komponen darah yang didapat setelah sebagian besar plasma dipisahkan dari whole blood dengan berbagai metode dan memiliki nilai hematokrit sebesar $80 \%$. Packed Red Cell disimpan pada suhu 2-6 ${ }^{\circ} \mathrm{C}$ selama 21-42 hari tergantung larutan antikoagulan-pengawet yang digunakan. Aktivitas pompa $\mathrm{Na}^{+} / \mathrm{K}^{+}$ATPase sangat dipengaruhi oleh suhu. Pompa menjadi inaktif pada suhu $4{ }^{\circ} \mathrm{C}$ menyebabkan kebocoran kalium ke plasma akibat kegagalan pompa $\mathrm{Na}^{+} / \mathrm{K}^{+}$ATPase, proses ini terjadi perlahan dan terus menerus sehingga kadar kalium pada plasma PRC meningkat seiring dengan bertambahnya waktu penyimpanan. Hiperkalemia merupakan komplikasi tersering transfusi darah simpan. Tujuan penelitian ini adalah mengetahui perbedaan kadar kalium PRC pada penyimpanan 4-14 hari dan > 14 hari di Bank Darah RSUP dr.M.Djamil Padang. Penelitian ini adalah suatu penelitian analitik dengan rancangan potong lintang. Penelitian ini dimulai bulan September 2016 sampai Agustus 2017. Kadar kalium diperiksa dengan metode ion selective electrode indirect (ISE indirect). Analisis data menggunakan uji t, bermakna bila $p<0,005$. Rerata kadar kalium pada penyimpanan 4-14 hari 3,9 $(0,8) \mathrm{mmol} / \mathrm{L}$ dan penyimpanan $>14$ hari $8,7(4,9) \mathrm{mmol} / \mathrm{L}$. Terdapat perbedaan bermakna rerata kadar kalium PRC berdasarkan lama penyimpanan menggunakan uji $t$ dengan rerata kadar kalium tertinggi pada penyimpanan $>14$ hari $(p=0,000)$. Terdapat perbedaan bermakna kadar kalium PRC berdasarkan lama penyimpanan dengan rerata kadar kalium PRC lebih tinggi pada penyimpanan $>14$ hari.
\end{abstract}

Kata kunci: jejas penyimpanan, kalium, packed red cell.

\begin{abstract}
Packed red cell (PRC) is final blood component after separation of most of plasma from whole blood (WB) in varies method with hematocrit $80 \%$. Packed red cell should be stored from sampling time until transfusion to recipient. Packed red cell is storaged in two until six degree celsius of temperature for twenty one until forty two days depend on anti coagulant-preservative that was used. $\mathrm{Na}^{+} / \mathrm{K}^{+} A T P a s e$ pump activity is very influenced by temperature. An inactive pump in four degree celsius leads to leakage of potassium to plasma, this process went so slowly and continue then plasma potassium level increases during storage period. Hyperkalemia is the most frequent complication from blood storage transfusion. Purpose of this study was to compare potassium level of PRC between four until fourteen days storage period and more than fourteen days. This was an analytical study with cross sectional design. This study was conducted from September 2016 until Augustus 2017. Potassium level was measured by ion selective electrode indirect (ISE indirect) method. $T$ test was used to analyse results and $p<0.005$ showed significant. Mean of potassium level in four until fourteen days storage was 3.955 (0.8430) $\mathrm{mmol} / \mathrm{L}$ and more than fourteen days storage 8.700 (4.9080) $\mathrm{mmol} / \mathrm{L}$. There was significant difference in mean of potassium level based on storage periods by test and more than fourteen days storage period showed higher mean $(p=0.000)$. There was significant different in PRC potassium level based on storage periods with higher potassium level in fourteen days storage.
\end{abstract}

Keywords: packed red cell, potassium, storage lesion

Affiliasi penulis : ${ }^{1}$ Program Studi Patologi Klinik FK Unand, ${ }^{2}$ Program Studi Patologi Klinik FK Unand,

Korespondensi : Tuti Asryani pdspatklin_pdg@yahoo.com

Pendahuluan

Packed Red Blood Cell (PRC) adalah

komponen darah yang didapat setelah sebagian besar plasma dipisahkan dari whole blood (WB) dengan berbagai metode dan memiliki nilai hematokrit sebesar 80\%. ${ }^{1}$ Packed Red Blood Cell masih mengandung leukosit, trombosit dan sedikit plasma. Satu unit PRC dengan volume $150-300 \mathrm{~mL}$ memiliki massa sel darah sekitar 100-200 mL.2 Transfusi eritrosit bertujuan untuk menggantikan atau memulihkan kapasitas darah mengangkut oksigen, oleh karena itu sangat diperlukan kualitas eritrosit yang baik. ${ }^{1,3}$

Packed red cell dapat disimpan mulai dari waktu pendonoran sampai ditransfusikan ke resipien. Tujuan penyimpanan PRC adalah menjaga viabilitas dan fungsi eritrosit dengan cara mengurangi aktivitas metabolisme sel. Packed red cell disimpan pada suhu $2-6^{\circ} \mathrm{C}$ selama 21-42 hari tergantung larutan antikoagulan-pengawet yang digunakan. Penurunan setiap satu derajat suhu penyimpanan dapat menurunkan aktivitas metabolisme sekitar $10 \% .^{1,5}$ Penyimpanan yang benar merupakan salah satu cara 
menjaga kualitas eritrosit. ${ }^{5}$ Standar peraturan saat ini mengharuskan 24 jam setelah transfusi lebih dari 75\% sel darah kembali pulih dalam sirkulasi. ${ }^{6}$

Selama dua dekade terakhir telah banyak dilakukan penelitian tentang kualitas dan kuantitas eritrosit selama periode penyimpanan, serta telah diidentifikasi berbagai macam perubahan yang terjadi selama penyimpanan eritrosit. Perubahan yang dialami eritrosit diantaranya adalah perubahan biokimia dan struktural yang akan memengaruhi viabilitas dan fungsi eritrosit setelah transfusi, perubahan tersebut dikenal dengan jejas penyimpanan eritrosit. $5,7,8$

Perubahan biokimia yang terjadi pada PRC akibat jejas penyimpanan eritrosit salah satunya adalah peningkatan kadar kalium pada plasma PRC. Aktivitas pompa $\mathrm{Na}^{+} / \mathrm{K}^{+}$ATPase sangat dipengaruhi oleh suhu. Pompa menjadi inaktif pada suhu $4^{\circ} \mathrm{C}$ menyebabkan kalium keluar dari sel dan natrium masuk kedalam sel. Selama penyimpanan darah terjadi kebocoran kalium ke plasma akibat kegagalan pompa $\mathrm{Na}^{+} / \mathrm{K}^{+}$ATPase, proses ini terjadi perlahan dan terus menerus. Kadar kalium pada plasma PRC dapat meningkat sebesar 0,5-1 $\mathrm{mmol} / \mathrm{L}$ perhari. Kalium bocor secara progresif dari eritrosit setelah tiga hari penyimpanan dan kadar ekstraselular dapat meningkat sampai $50 \mathrm{mmol} / \mathrm{L}$. Puncak kadar kalium plasma PRC setelah dua minggu penyimpanan dapat mencapai $90 \mathrm{mmol} / \mathrm{L} .9,10,11$

Beberapa penelitian dilakukan untuk mengetahui kadar kalium pada plasma PRC yang dikaitkan dengan lama penyimpanan. Penelitian yang dilakukan oleh di Minnesota menyimpulkan bahwa kalium meningkat seiring waktu penyimpanan PRC, kadar kalium plasma PRC meningkat sebesar 77,0 $\mathrm{mmol} / \mathrm{L}$ pada hari ke-14 penyimpanan ${ }^{14}$. Penelitian oleh di Republik Ceko tentang perubahan biokimia pada plasma pasien setelah transfusi PRC, mendapatkan peningkatan kadar kalium plasma PRC dari $4 \mathrm{mmol} / \mathrm{L}$ menjadi $7,3 \mathrm{mmol} / \mathrm{L}$ untuk rerata lama penyimpanan 16,3 hari, dan tidak ditemukan peningkatan kadar kalium plasma PRC untuk rerata lama penyimpanan 14,6 hari, dan untuk rerata penyimpanan 11,7 hari kadar kalium ditemukan menurun pada plasma $\mathrm{PRC}^{19}$.
Hiperkalemia merupakan komplikasi tersering pada transfusi darah simpan. Henti jantung telah banyak dilaporkan pada transfusi yang berhubungan dengan hiperkalemia. Beberapa penelitian menduga bahwa dampak klinis jejas penyimpanan menjadi bermakna setelah dua minggu penyimpanan. ${ }^{12,13,14}$ Penelitian di Inggris tahun 2008 melaporkan pada 6.002 pasien bedah jantung yang menerima tranfusi PRC baik $\leq 14$ hari atau $>14$ hari, terdapat hubungan yang bermakna antara kematian dan waktu penyimpanan darah ${ }^{20}$. Penelitian di Australia tahun 2008 melaporkan transfusi unit PRC yang disimpan lama (lebih dari dua minggu) berhubungan dengan peningkatan risiko komplikasi setelah operasi dan tingkat kematian ${ }^{21}$.

Berdasarkan latar belakang diatas dan belum dilakukan penelitian tentang perbandingan kadar kalium PRC berdasarkan lama penyimpanan di bank darah RSUP Dr. M. Djamil Padang, maka peneliti tertarik untuk melakukan penelitian tentang kadar kalium PRC yang disimpan di bank darah RSUP Dr. M. Djamil Padang.

\section{Metode}

Penelitian ini adalah penelitian analitik dengan rancang potong lintang yang dilakukan di Laboratorium sentral dan Bank Darah RSUP dr. M. Djamil Padang terhitung September 2016 sampai Agustus 2017. Sampel penelitian sebanyak 22 unit PRC diperoleh dari 11 unit PRC yang disimpan selama 4-14 hari dan 11 unit PRC yang disimpan selama $>14$ hari, unit PRC yang hemolisis secara visual dikeluarkan dari penelitian ini. Plasma PRC sebanyak $95 \mu \mathrm{L}$ diperoleh dari selang kantong darah dan kadar kalium diperiksa menggunakan metode ion selective electrode indirek. Hasil penelitian dianalisis secara statistik menggunakan metode uji $t$, hasil dianggap mempunyai perbedaan bermakna jika $p<0,05$.

\section{Hasil}

Penelitian ini dilakukan terhadap 22 unit PRC yang diperoleh dari 11 kantong darah dengan lama penyimpanan 4-14 hari dan 11 kantong darah dengan lama penyimpanan $>14$ hari yang memenuhi kriteria inklusi dan eksklusi pada bulan Mei 2017. Rerata kadar kalium plasma PRC berdasarkan lama penyimpanan dapat dilihat pada tabel 1. 
Tabel 1. Rerata kadar kalium plasma PRC berdasarkan lama penyimpanan

\begin{tabular}{lll}
\hline $\begin{array}{c}\text { Lama } \\
\text { Penyimpanan } \\
\text { (Hari) }\end{array}$ & $\begin{array}{c}\text { Rerata Kalium } \\
\text { Plasma PRC } \\
\text { mmol/L (SD) }\end{array}$ & \\
\hline 4-14Ari & $3,9(0,8)$ & ${ }^{*} 0,000$ \\
$>14$ hari & $8,7(4,9)$ & \\
\hline Uji t $p=0,000$ & & \\
$*=$ bermakna $(p<0,05)$
\end{tabular}

\section{Berdasarkan uji normalitas Shapiro-Wilk} didapatkan data kadar kalium plasma PRC terdistribusi normal (gambar 1). Perbedaan rerata kadar kalium plasma PRC 4-14 hari dan $>14$ hari menggunakan uji $\mathrm{t}$ didapatkan perbedaan bermakna dengan nilai $p=0,000$ dan rerata kadar kalium plasma $P R C$ lama penyimpanan $>14$ hari lebih tinggi.

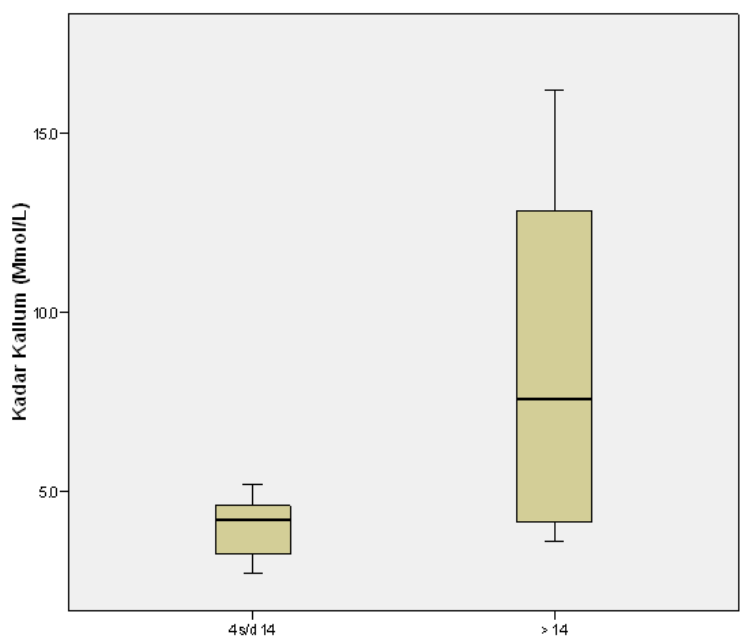

Gambar 1. Box Plot Distribusi Data Kadar Kalium PRC

\section{Pembahasan}

Masalah utama pada PRC simpan adalah jejas penyimpanan in vitro yang merusak fungsi eritrosit dan dapat memengaruhi metabolisme in vivo resipien. ${ }^{15}$ Penelitian ini mendapatkan peningkatan bermakna kalium PRC pada lama penyimpanan 4-14 hari $3,9(0,8) \mathrm{mmol} / \mathrm{L}$ dan lama penyimpanan $>14$ hari $8,7(4,9) \mathrm{mmol} / \mathrm{L}(\mathrm{p}=0,000)$. Hal serupa juga didapatkan oleh penelitian lain. Penelitian di Amerika Serikat mendapatkan hasil yang hampir sama, dengan kadar kalium PRC pada lama penyimpanan 7 hari $14,4(0,8)$ $\mathrm{mmol} / \mathrm{L}$, lama penyimpanan 14 hari $22,8(2,5) \mathrm{mmol} / \mathrm{L}$, lama penyimpanan 21 hari 29,9(2,9) $\mathrm{mmol} / \mathrm{L}$, lama penyimpanan 42 hari 44,2(3,5) $\mathrm{mmol} / \mathrm{L}$ dengan $p<0,05^{23}$. Penelitian di Indonesia tentang kadar kalium pada PRC simpan juga mendapatkan peningkatan rerata kadar kalium pada penyimpanan hari pertama $3,79 \mathrm{mmol} / \mathrm{L}$, pada hari ke-10 sebesar 12,22 $\mathrm{mmol} / \mathrm{L}$, pada hari ke-20 sebesar $19,77 \mathrm{mmol} / \mathrm{L}$, perbedaan bermakna dengan $p=0,00^{22}$. Penelitian oleh di Republik Ceko mendapatkan peningkatan menetap kadar kalium PRC tergantung pada lama penyimpanan $^{19}$.

Tujuan penyimpanan PRC adalah menjaga viabilitas dan fungsi eritrosit dengan cara mengurangi aktivitas metabolisme sel. Packed red cell disimpan pada suhu $2-6^{\circ} \mathrm{C}$ selama $21-42$ hari tergantung larutan antikoagulan-pengawet yang digunakan. Penurunan setiap satu derajat suhu penyimpanan dapat menurunkan aktivitas metabolisme sel sekitar $10 \% .^{1,4}$ Selama penyimpanan pada eritrosit dapat terjadi serangkaian perubahan baik biokimia, biomekanik, dan imunologik yang dapat menurunkan kelangsungan hidup dan fungsi eritrosit. ${ }^{5,16}$ Peningkatan kadar kalium merupakan salah satu perubahan biokimia akibat jejas penyimpanan. Aktivitas pompa $\mathrm{Na}^{+} / \mathrm{K}^{+} \mathrm{ATPase}$ sangat dipengaruhi oleh suhu. Pompa menjadi inaktif pada suhu $4^{\circ} \mathrm{C}$ menyebabkan kalium keluar dari sel dan natrium masuk kedalam sel. Penyimpanan PRC pada suhu $2-4^{\circ} \mathrm{C}$ menyebabkan kebocoran kalium intraseluler kedalam plasma PRC. $\mathrm{Hal}$ ini berlangsung lambat dan terus menerus. ${ }^{13}$

Kadar kalium PRC yang disimpan 4-14 hari berbeda bermakna dengan penyimpanan $>14$ hari karena diperkirakan jumlah ATP dan glukosa dalam kantong darah masih mencukupi untuk metabolisme sel dan $\mathrm{pH}$ belum terlalu mengalami penurunan pada penyimpanan 4-14 hari. Proses metabolisme sel terus berlangsung seiring dengan bertambahnya waktu penyimpanan, kadar ATP dan glukosa dalam kantong darah akan mengalami penurunan karena digunakan untuk metabolisme sel yang energinya berasal dari proses glikolisis. Asam laktat sebagai hasil glikolisis akan terus menumpuk menyebabkan keadaan lingkungan menjadi asam ( $\mathrm{pH}$ menurun). Penurunan $\mathrm{pH}$ akan semakin menghambat kerja pompa $\mathrm{Na}^{+} / \mathrm{K}^{+}$ATPase sehingga kadar kalium PRC akan semakin meningkat sebanding dengan lama penyimpanan. ${ }^{17}$

Eritrosit mengandung sedikit mitokondria dan sangat tergantung pada glikolisis untuk kebutuhan energinya. Packed red cell yang disimpan pada suhu 4 ${ }^{\circ} \mathrm{C}$ yaitu suhu yang memperlambat metabolisme, mengurangi produksi ATP dan berbagai fungsi eritrosit 
yang memerlukan energi. Laju glikolisis tergantung pada suhu dan $\mathrm{pH}$. Perubahan metabolisme meliputi penurunan glikolisis dan produksi ATP setelah satu minggu penyimpanan, hal ini menyebabkan akumulasi laktat dan penurunan $\mathrm{pH} .{ }^{10,15}$ Suatu penelitian pernah melaporkan restorasi gradien kation setelah inkubasi dengan glukosa pada suhu $37^{\circ} \mathrm{C}$ dan penelitian ini menggunakan darah yang disimpan selama 6 hari dimana kadar ATP masih tinggi. Penelitian tahun 2014 menjelaskan terdapat variasi alami terhadap laju kebocoran kalium melewati membran sel. Pada kehidupan sehari-hari variasi ini tidak berdampak karena kontribusi $\mathrm{Na}^{+} / \mathrm{K}^{+}$ATPase dalam mempertahankan gradien kation yang berfungsi untuk mengontrol volume vaskular dan hidrasi. ${ }^{18}$

Penelitian di Ghana, tentang perubahan kadar kalium dan natrium pada darah simpan mendapatkan hasil kadar kalium PRC pada hari-0 sebesar 3,31 $\mathrm{mmol} / \mathrm{L}$, pada hari-5 sebesar 8,66 $\mathrm{mmol} / \mathrm{L}$, pada hari-10 sebesar $12,83 \mathrm{mmol} / \mathrm{L}$, pada hari ke-14 sebesar $14,19 \mathrm{mmol} / \mathrm{L}$ dan pada hari ke-20 sebesar 14,98 mmol/L. Pada penelitian tersebut terlihat bahwa perubahan kadar kalium hari ke-14 dan hari ke-21 tidak menunjukkan peningkatan yang signifikan ${ }^{10}$. Hal tersebut berbeda dengan hasil penelitian ini, mungkin dikarenakan $\mathrm{pH}$ pada hari penyimpanan tersebut belum mengalami penurunan yang bermakna sehingga kebocoran kalium berjalan lambat. $\mathrm{pH}$ merupakan penanda penting metabolisme eritrosit yang melambat seiring penurunan $\mathrm{pH}$ selama penyimpanan.

Pada penelitian ini didapatkan perbedaan bermakna kadar kalium PRC berdasarkan lama penyimpanan dengan rerata kadar kalium PRC lebih tinggi pada penyimpanan $>14$ hari. Berdasarkan hasil penelitian ini peneliti menyarankan untuk dilakukan penelitian lebih lanjut terhadap parameter lain yang mengalami perubahan selama penyimpanan PRC seperti kadar ATP dan $\mathrm{pH}$, serta penelitian terhadap kadar kalium plasma pasien sebelum dan sesudah transfusi PRC sesuai dengan lamanya penyimpanan di Bank Darah Rumah Sakit.

\section{Daftar Pustaka}

1. Mc Cullough J. Preparation, Storage, and Characteristic of Blood Components and Plasma Derivatives. Dalam: Transfusion Medicine. Edisi ke-3. New Delhi: Blackwell Publishing Ltd; 2012. hIm. 68-77.

2. Beutler E. Preservation and Clinical Use of Erythrocyte and Whole Blood: Overview. Dalam: William Haematology. Edisi ke-7. New York: McGraw Hill Companies; 2007. hlm. 2287-301.

3. Sacher R, Mc Person R. IImu Kedokteran Transfusi. Dalam Tinjauan Klinis Hasil Pemeriksaan Laboratorium. Edisi ke-11. Jakarta: EGC; 2002. hlm. 235-40.

4. Hess JR, Beyer GM. Red Blood Cell Metabolism during Storage : Basic Principles and Practical Aspects. Dalam: Blood Banking and Transfusion Medicine. Edisi ke-2. USA: Churcill Livingstone; 2007. hlm. 205-11.

5. Daryl J, Camille M, Ognjen G. Red Blood Cell Storage Lesion. Bosnian Journal of Basic Medical Sciences, 2009; 9 supplement 1:21-7.

6. Harmening D, Moroff G. Red Blood Cell and Platelet Preservation: Historical Perspectives. Review of Metabolic and Current Trends. Modern Blood Banks and Transfusion Practices. 5th edition. Davis Company, 2005;1-18.

7. Leo MG, Anneke B. Effects of storage of Red Cells. Transfusion Medicine and Chemotheraphy, 2008;35(5):359-67.

8. Daniel B, Kim S, Janet L, Mark T. Storage Lesion: Role Of Red Cell Breakdown. Transfusion. 2011; 51(4): 844-8.

9. D'Alessandro A, Liumbruno G, Grazzini, G, Zolla L. Red Blood Cell Storage: The Story So Far. Blood Transfus. 2010; 8(2): 82-8.

10. Opoku-Okrah C, Acquah BKS, Dogbe EE. Changes In Potassium and Sodium Concentration In Stored Blood. Pan African Medical Journal. 2015;20(1):1-6.

11. Raza S, Baig M, Chang C, Dabas R, Akhtar M, Khan A, et al. A Prospective Study On Red Blood Cell Transfusion Related Hyperkalemia In Critically III Patients. Original Article J Clin Med Res, 2015;7(6):417-21.

12. Smith H, Farrow S, Ackerman J, Stubbs J, Sprung J. Cardiac Arrest Associated with Hyperkalemia Red Blood Cell Transfusion. Anesthesi Analg. 2008;106(4):1062-9. 
13. van de Watering $L$, Brand A. Effects Of Storage Of

Red Cells. Review Article Transfusion Medicine and Hemotherapy.2008;100(1):359-67.

14. Lelubre C, Louis V. Relationship Between Red Cell Storage Duration and Outcomes. Adults Receiving Red Cell Transfusion: A Systematic Review. Crit Care. 2013;17(2):1-18.

15. Mukherjee S, Marwaha N, Prasad R, Sharma R, Thakral B. Serial Assessment of Biochemical Parameters of Red Cell Preparations to Evaluate Safety for Neonatal Transfusions. Indian J Med Res. 2010; (132):715-20.

16. Brecher ME. Collection, preparation, storage and distribution of components from whole blood donation. Dalam: Technical Manual. Edisi ke-5. Maryland (USA): AABB;2005. hlm.175-202.

17. Opoku-Okrah C, Acquah BKS, Dogbe EE. Changes in Potassium and Sodium Concentration in Stored Blood. Pan African Medical Journal. 2015;20(1):1-6.

18. Flatt J, Bawazir W, Bruce L. The Involvement of Cation Leaks in The Storage Lesion of Red Blood Cells. Review Article. 2014;5(214):1-9.

19. Uvizl R, Klementa B, Adamus, Neise J. Biochemical Changes in The Patients Plasma After Red Blood Cell Transfusion. Signa Vitae. 2011;6(2):64-71.

20. Koch CG, Li L, Sessler D, Figueroa P, Hoeltge G, Mihaljevic T, et al. Duration of Red Cell Storage and Complications After Cardiac Surgery. New England Journal Medicine. 2008; 358:1229-39.

21. Yap $\mathrm{CH}$, Lau L, Khrisnaswamy M, Gaskell M, Yii M. Age of Transfused Red Cells and Early Outcomes After Cardiac Surgery. Ann Thorac Surg. 2008; 86:554-9.

22. Sutjianto A, Nurulita A, Mangarengi F. Kadar Kalium Di Packed Red Cell Simpanan. Indonesian Journal of Clinical Pathology and Medical Laboratory. 2014; 22(2):147-9.

23. Karon B, Buskirk C, Jaben E, Hoyer J, Thomas D. Temporal Sequence of Major Biochemical Events During Blood Bank Storage of Packed Red Blood Cells. Blood Transfusion. 2012; 10:453-61. 